\title{
THEORETICAL BASIS OF JUSTIFICATION OF ELECTROMECHANICAL HARDENING MODES OF MACHINE PARTS
}

\author{
Mikhail Erokhin ${ }^{1}$, Alexander Pastukhov ${ }^{2}$, Ivan Golubev ${ }^{3}$, Sergey Kazantsev ${ }^{1}$ \\ ${ }^{1}$ Russian Timiryazev State Agrarian University, Russia; ${ }^{2}$ Belgorod State Agricultural University \\ named after V. Gorin, Russia; ${ }^{3}$ Rosinformagrotech, Research Center Agroinnovation, Russia \\ er.mihn@mail.ru,pastukhov_ag@mail.ru,golubev@rosinformagrotech.ru, kspts@bk.ru
}

\begin{abstract}
In the practice of agricultural machine building and repair of machines, technological methods of surface hardening are widely used, which significantly increase wear resistance and durability of parts. Combined methods of combining temperature, force and time effects in different manifestations, in particular electromechanical hardening, are particularly effective. The purpose of the study is to identify the relationships between the modes and parameters of the process of electromechanical hardening for parts of machines made of unalloyed and low-alloy structural quality steels. The hardening modes include: magnitude of the force and voltage of the amperage on the hardening tool, contact force of the tool to the part. The parameters of the technological process are: speed of rotation of the part, central angle of contact between the tool and the part, time of point contact between the part and the tool, presence of forced cooling, depth of hardening. Among the tested materials - steel $65 \mathrm{G}$ and its substitutes according to GOST 14959, foreign analogues 1056 (USA), 66 Mn4 (Germany) and 080A67 (England). Based on theoretical relationships between the temperature of phase transformations in steels, amperage on the tool and force of its pressing, taking into account thermophysical characteristics of the material and process of electromechanical hardening, as well as geometrical parameters of contact zone, a mathematical model of dependence of current force at strengthening from of tool contact force and voltage in secondary circuit is obtained with subsequent quantitative estimation of depth of strengthening of the surface layer of the part. In order to study mutual couplings and influence of factors on response functions at studies of the hardening technological process the graphical interpretation of the mathematical model is performed, which allows to justify range of modes of electromechanical hardening at planning of experiments.
\end{abstract}

Keywords: machine part, electromechanical hardening, amperage, contact force, depth of hardening.

\section{Introduction}

Reliability control during operation of power, transport and technological machines contains a list of works during maintenance and repair, at the same time preparation of repair production, training of personnel, development of normative and technical documentation, restoration of technical condition, carrying out tests and evaluation of life of repaired products are mandatory. The main requirement at the stage of machine operation is to ensure operable technical conditions of units and assemblies, which is provided by application of methods of hardening and/or restoration of working surfaces of machine parts [1]. In agriculture, not a small proportion of the cost of production is the cost of maintenance and repair, which is about an order of magnitude higher than the cost of new equipment.

Analysis of technical literature and review of studies in the field of ensuring reliability of products by methods of strengthening and restoration of working surfaces of parts show that the real reduction of the mentioned costs is constant improvement and development of rational methods of restoration of the technical condition of machine parts to the level of new products $[2 ; 3]$. The world trend of innovative development of repair and maintenance of power, transport and technological machines is characterized by development and implementation of technological solutions in agricultural machine building with regard to restoration of machine part operability with application of combined methods of combination of temperature, power and time effects in various manifestations, for example, laser, electromechanical and other types of treatment $[4 ; 5]$. As the cost of the electromechanical processing equipment is considerably lower, the electromechanical processing method is the most preferable, but the methods of implementing hardening for different machine parts are varied due to different technical requirements, besides, the issues of theoretical justification and coordination of processing modes and process parameters are not deeply disclosed [2-7].

The purpose of the study is to identify the relationships between the modes and parameters of the process of electromechanical hardening for parts of machines made of carbon and low-alloy structural quality steels.

To achieve this goal, the following objectives must be achieved:

1. development of theoretical bases of electromechanical treatment of machine parts; 
2. design evaluation of relationships of modes and parameters of the process of electromechanical hardening on the example of parts of machines made of carbon and low-alloyed structural quality steels;

3. analysis and synthesis of the results obtained, disclosure of research prospects.

\section{Materials and methods}

In the practice of electromechanical hardening, the main performance characteristics of machine parts are determined by the influence of structural, technological and operational factors. Structural factors include geometric and precision parameters of parts, physical-mechanical and chemical properties of the material; process factors - thermal and mechanical treatment parameters; operational - parameters and characteristics of part operability, for example, limit of part fatigue and hardness of surfaces.

In combination, structural and technological factors determine modes (force and voltage of electric current on the strengthening tool, force of pressing the tool against the part) and parameters (speed of rotation of the part, central angle of contact between the tool and the part, duration of point contact between the part and the tool, cooling speed, depth of strengthening) of the process of electromechanical hardening, and operational factors allow to estimate the operability of the strengthened parts by wear or destruction.

Technical essence of electromechanical hardening is based on combination of thermal and force action on the surface layer of the processed part by means of a tool. At the same time, electric current of high force and low voltage passes through the place of contact of the tool with the part, which leads to strong heating of surface irregularities, which are deformed and smoothed under the pressure of the tool, and the surface layer due to rapid cooling experiences quenching and therefore is hardened [5].

The thermal balance of the thermomechanical treatment process shows that the total amount of heat $Q, \mathrm{~J}$, is made up of heat generated by the passing electric current $Q_{1}, \mathrm{~J}$, heat from the friction of the tool against the surface to be treated $Q_{2}, \mathrm{~J}$, and the heat generated by the plastic deformation of the material $Q_{3}$, J, according to the equation (1).

$$
Q=Q_{1}+Q_{2}+Q_{3} .
$$

The amount of heat $Q_{1}$, J, generated by the passage of electric current through the tool and part contact is determined by the expression (2).

$$
Q_{1}=0.24 \cdot 10^{-3} \eta I U \frac{\pi L D i}{S V},
$$

where $0.24 \cdot 10^{-3}-$ ratio of proportionality and reduction;

$\eta$ - coefficient of electric current loss in secondary circuit;

$I-$ current intensity in secondary circuit, A;

$U$ - voltage of electric current in secondary circuit, $\mathrm{V}$;

$L-$ length of the treated surface, $\mathrm{m}$;

$D$ - treated surface diameter, $\mathrm{m}$;

$i$ - number of hardening passes;

$S$ - lathe machining feed, $\mathrm{mm} \cdot$ turn $^{-1}$;

$V$ - actual circumferential surface treatment speed, $\mathrm{m} \cdot \mathrm{min}^{-1}$.

The amount of heat from friction of the tool against the workpiece $Q_{2}, \mathrm{~J}$ during hardening is determined by the formula (3).

$$
Q_{2}=P_{\mathrm{k}} H f_{\mathrm{k}} / 102,
$$

where 102 - reduction coefficient;

$P_{\mathrm{k}}$ - force in tool-to-part contact, N;

$H$ - height of the high-temperature zone at part hardening in contact, $\mathrm{m}$;

$f_{\mathrm{k}}$ - sliding friction coefficient at steady-state processing treatment.

The equation for determining the amount of heat $Q_{3}$, J released by plastic deformation of the part material during processing is (4). 


$$
Q_{3}=P_{\mathrm{k}} n_{i} / E,
$$

where $n_{i}$ - rotary speed of the tool, $\min ^{-1}$;

$E-$ mechanical equivalent of heat, $\mathrm{kg} \cdot \mathrm{m} \cdot \mathrm{kcal}^{-1}$.

The total amount of heat $Q_{\mathrm{t}}, \mathrm{J}$, absorbed in the high-temperature contact zone of the tool and the workpiece during the processing time $\tau$, c, is expressed by the formula (5).

$$
Q_{\mathrm{t}}=Q k_{\mathrm{p}} k_{\mathrm{i}}
$$

where $k_{p}$ - heat removal factor to the part;

$k_{i}$ - coefficient of heat removal to the tool.

The processing time of the part $\tau, \mathrm{s}$, in the process is predetermined by geometric parameters of the part and processing modes on the machine according to the formula (6).

$$
\tau=L i / n S,
$$

where $n$ - rotary speed of the part, $\min ^{-1}$.

Analysis of the thermal processes of the high-temperature contact zone of the tool and part shows that the thermal balance, taking into account the thermophysical properties of the material and the temperature values of the critical points of phase transformations, is expressed by the equation (7).

$$
Q_{\mathrm{t}}=H B h_{h} \gamma C T_{\mathrm{h}},
$$

where $B$-width of the high-temperature zone in contact, $\mathrm{m}$;

$h_{h}$ - depth of the hardened layer, m;

$\gamma$ - part material density, $\mathrm{kg} \cdot \mathrm{m}^{-3}$;

$\mathrm{C}$ - specific heat capacity of metal, $\mathrm{J} \cdot\left(\mathrm{kg} \cdot{ }^{\circ} \mathrm{C}\right)^{-1}$;

$T_{h}$ - temperature of metal phase transformations, ${ }^{\circ} \mathrm{C}$.

Equalizing the expressions of the total heat generated by thermomechanical treatment and the heat amount obtained from the heat balance equation, we obtain the expression linking the parameters of the part and the tool, as well as the modes of the electromechanical treatment process in the form of the equation (8).

$$
\left(0.24 \cdot 10^{-3} \eta I U \frac{\pi L D i}{S V}+\frac{P_{\mathrm{k}} H f_{\mathrm{k}}}{102}+\frac{P_{\mathrm{k}} n_{i}}{E}\right) k_{\mathrm{p}} k_{\mathrm{i}}=H B h_{h} \gamma C T_{\mathrm{h}} .
$$

The main purpose of the description of the hardening treatment process is to predict the depth of the surface metal layer of the part to be hardened, so from the formula (8) after conversion we obtain a mathematical model for calculation of the value of the hardened layer (9).

$$
h_{h}=\left(0.24 \cdot 10^{-3} \eta I U \frac{\pi L D i}{S V}+\frac{P_{\mathrm{k}} H f_{\mathrm{k}}}{102}+\frac{P_{\mathrm{k}} n_{i}}{E}\right) k_{\mathrm{p}} k_{\mathrm{i}} /\left(H B \gamma C T_{\mathrm{h}}\right) .
$$

The formula for evaluating the value of the hardened layer as a final hardening indicator should be converted to a more convenient form, as unalloyed and low-alloy structural quality steels have the same heat capacity, density and other constant parameters that allows to introduce complex coefficients $A_{i}$ to determine the share of contribution to the final hardening of three heat sources: from passing electric current taking into account processing modes $\left(A_{1}\right)$, from friction of the tool against the surface to be treated $\left(A_{2}\right)$ and at plastic deformation of material $\left(A_{3}\right)$ according to the equations $(10)-(13)$.

$$
\begin{gathered}
A_{1}=\frac{0.24 \cdot 10^{-3} \eta U \pi L D i k_{\mathrm{p}} k_{\mathrm{i}}}{V S H B \gamma C T_{\mathrm{h}}}, \\
A_{2}=\frac{H f_{\mathrm{k}} k_{\mathrm{p}} k_{\mathrm{i}}}{102 H B \gamma C T_{\mathrm{h}}},
\end{gathered}
$$




$$
\begin{gathered}
A_{3}=\frac{n_{i} k_{\mathrm{p}} k_{\mathrm{i}}}{E H B \gamma C T_{\mathrm{h}}}, \\
h_{h}=A_{1} I+A_{2} P_{\mathrm{k}}+A_{3} P_{\mathrm{k}} .
\end{gathered}
$$

In the practical implementation of technological methods for improving the operability of parts during restoration and hardening, it is necessary to take into account the structure of the metal to be treated and the minimum temperature of phase transformation of steels. For parts of tractors, agricultural machinery and equipment, most are parts made of carbon and low alloy structural quality steels, for example: 1) steel 18HGT and its substitutes 30HGT, 25HGT, 12HN3A, 12H2N4A, 20HN2M, 14HGCN2MA, 20HGR in accordance with GOST 4543 and substitutes 20Mn5G (Germany), 20MC5 (France), 20CrMnTi (China); 2) steels 40, 45, 50 in accordance with GOST 1050 and steels 40H, 40HN in accordance with GOST 4543 and substitutes 1040 and 5140 (USA), C40 and 41Cr4 (Germany), 060A40 and 530H40 (England), S40C and Scr440 (Japan); 3) steel 65G, its substitutes in accordance with GOST 14959 (steels 70, U8A, 70G, 60C2A, 9HC, 50HFAU, 60C2, 55C2) and substitutes 1566 (USA), 66Mn4 (Germany), SUP6 (Japan), 080A67 (England). In the first case, the minimum phase conversion temperature is about $825^{\circ} \mathrm{C}$, in the second case $780^{\circ} \mathrm{C}$ and in the third case $745^{\circ} \mathrm{C}$.

\section{Results and discussion}

We will carry out design evaluation of electromechanical hardening modes at certain constant values of the following parameters: $\eta=0.42, \quad U=2-4 \mathrm{~V}, L=0.1 \mathrm{~m}, D=0.01 \mathrm{~m}, \quad i=1$, $V=0.00525 \mathrm{~m} \cdot \mathrm{s}^{-1}, S=0.001 \mathrm{~mm} \cdot \mathrm{turn}^{-1}, k_{\mathrm{p}}=0.234, k_{\mathrm{i}}=0.5-0.6, H=0.001 \mathrm{~m}, B=0.001 \mathrm{~m}, f_{\mathrm{k}}=0.10$, $\gamma=7.85 \mathrm{~g} \cdot \mathrm{sm}^{-3}, \quad C=486 \mathrm{~J} \cdot\left(\Gamma \cdot{ }^{\circ} \mathrm{K}\right)^{-1}, \quad T_{\mathrm{h}} \approx 800-900^{\circ} \mathrm{C}, \quad E=427 \mathrm{~kg} \cdot \mathrm{m} \cdot \mathrm{kcal}{ }^{-1}, \quad n_{i}=10 \mathrm{~min}^{-1}$. After calculations of average values of parameters on the basis of formulas (10)-(12) we obtain the following values of complex coefficients: $A_{1}=7.178 \cdot 10^{-4}, A_{2}=3.891 \cdot 10^{-8}, A_{3}=9.427 \cdot 10^{-4}$.

Based on the technical capabilities and practical experience of the plant for electromechanical processing "UEMO-Standard", we set the range of current intensity values on the instrument $I=600 \ldots 1500 \mathrm{~A}$ and the value of the tool pressing force to the part $P_{\mathrm{k}}=100 \ldots 500 \mathrm{~N}$. Based on the equation (13) and the values of the complex coefficients of $A_{1}, A_{2}$ and $A_{3}$, we will perform a graphical interpretation of the relationship between the modes and parameters of the process of electromechanical hardening represented by Fig. 1.

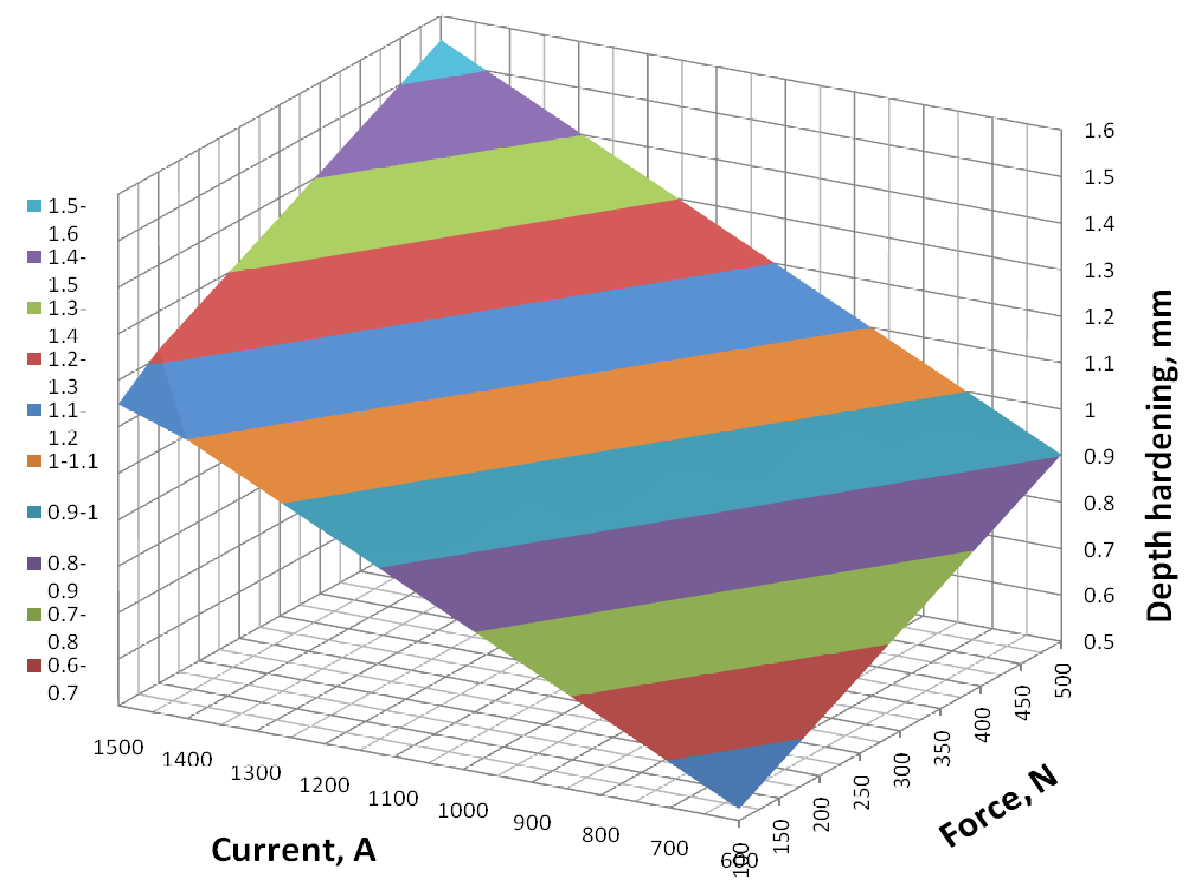

Fig. 1. Dependence of hardening depth on current and tool pressing force $h_{h}=f\left(I, P_{\mathrm{k}}\right)$ 
Data analysis in Fig. 1 shows that with an increase in the current from 600 to 1500 A when the tool is hardened and the pressing force of the tool against the part from 100 to $500 \mathrm{~N}$, the depth of the hardened layer increases linearly from 0.5 to $1.5 \mathrm{~mm}$, which corresponds to the range of values of technical requirements of parts, does not contradict the theory of thermal treatment of metals and is explained by the increase of heat supply and stabilization of conditions of contact of the hardening roller with the part, as well as by application of average values.

However, in the first approximation, the relationships of the parameters under consideration are non-linear, as confirmed by previous experimental studies of the process of hardening during electromechanical processing using the example of tractor parts and agricultural equipment $[8 ; 9]$.

In particular, during electromechanical hardening of the spikes of the crosses of the cardan joints made of steels 45 and 55PP according to GOST 1050, the hardening efficiency was estimated by the operational properties of the working surfaces, in particular, by the hardness before and after hardening of the spikes and compared with the hardness of the spikes of the steel cross $20 \mathrm{H}$ GOST 4543 [8]. On the basis of the plan of the complete factor experiment at the current intensity $I=800$ $1200 \mathrm{~A}$ and the force in contact of the tool and part $P_{\mathrm{k}}=300-500 \mathrm{~N}$, hardness of the spikes in Rockwell units of HRC was estimated. The multiple regression analysis results in empirical mathematical models establishing the relationship between the hardening modes and the surface hardness of the spikes in equations (14) and (15).

$$
\begin{aligned}
& H R C_{45}=-219.176+0.587 I-0.394 P_{k}-2.39 \cdot 10^{-4} I^{2}- \\
& -1.73 \cdot 10^{-4} I P_{k}+7.36 \cdot 10^{-4} P_{k}^{2} \\
& H R C_{55 \mathrm{PP}}=-28.389+0.176 I-0.360 P_{k}-7.71 \cdot 10^{-5} I^{2}+ \\
& +7.92 \cdot 10^{-5} I P_{k}+3.75 \cdot 10^{-4} P_{k}^{2}
\end{aligned}
$$

The coefficients of empirical equations are significant by Student criterion, and the multiple regression equations are sufficiently determined by Fisher criterion at $\mathrm{P}=0.95$. Solving equations on the basis of mathematical analysis methods shows that the greatest hardness of spikes in the experiment is provided at $I=950-1100$ A and $P_{\mathrm{k}}=350-400 \mathrm{~N}$ [8].

Similar studies were carried out when working out modes of electromechanical strengthening of a plunger made of steel $40 \mathrm{H} 13$ GOST 5632, at the same time the current intensity was $I=800 \ldots 1200 \mathrm{~A}$, tool pressing force $P_{\mathrm{k}}=100 \ldots 300 \mathrm{~N}$, and evaluation of the hardening effect was carried out by hardness of reinforced sections according to Rockwell scale HRC [9]. Mathematical regression model of influence of factors on the plunger hardness in decoded form is presented as (16).

$$
H R C=40.321-0.148 I+0,499 P_{k}+1.01 \cdot 10^{-4} I^{2}-1.44 \cdot 10^{-4} I P_{k}-6.22 \cdot 10^{-4} P_{k}^{2} .
$$

The coefficients of the model are significant by Student criterion, and the empirical model itself is sufficiently determined by Fisher criterion at $P=0.95$. Solving the equation shows that the greatest plunger hardness is provided at $I=950-1000 \mathrm{~A}$ and $P_{\mathrm{k}}=300-350 \mathrm{~N}$ [9].

The final evaluation of the reinforced parts showed an increase in hardness of the working surfaces by a factor of 1.5-2.0, which is the basis of formation of their wear resistance [8;9].

Analysis of applied research in the field of electromechanical processing shows that similar results were obtained by researchers when hardening the hole of the wheel cylinder of the rear brake of the UAZ vehicle using surface electromechanical tillage [10], when electromechanical hardening the blades of the ploughshares of sowing machines [11] and the working surfaces of tubing steels [12], but data on theoretical justification of the hardening modes were not given by the authors.

\section{Conclusions}

1. The main factors of influence on operational characteristics of working surfaces subjected to hardening are modes, for example, the current intensity and tool pressing force, at the same time in theory the relationships between them are linear, and in practice have a non-linear connection, which allows after preliminary selection to justify optimal modes ensuring maximum hardness of surfaces. 
2. Analysis of the calculated evaluation of the effect of the tool current and pressing force on the depth of the part hardening shows that the proportion of the current force is more than $60 \%$, and the pressing force is about $40 \%$. The results of the experiments confirm greater effect of electromechanical reinforcement current on the performance of the parts.

3. Prospects for development of methods of electromechanical hardening and restoration of parts of agricultural machines and processing equipment lie in wide distribution and introduction in conditions of repair enterprises.

\section{References}

[1] Lamberson L.R., Kapur K.S. Reliability in engineering design. Weliy India Pvt. Limited, 2009. $608 \mathrm{p}$.

[2] Fedorova L.V., Fedorov S.K., Ivanova Y.S., Voronina M.V. Increase of wear resistant of the drill pipe thread connection by electromechanical surface hardening. International Journal of Applied Engineering Research. 2017. Vol. 12 (18). pp. 7485-7489.

[3] Alekseeva J.S., Fedorova L.V., Fedorov S.K., Kapustin I.N. Improving the quality of the surface layer of steel parts. Proceeding of 5-th International Mechanical Engineering Forum (IMEF), Prague Czech Republic, 2012, pp. 65-74.

[4] Черноиванов В.И., Лялякин В.П., Голубев И.Г. Организация и технология восстановления деталей машин: научное издание. Москва: ФГБНУ Росинформагротех, 2016. 568 с. (Chernoivanov V.I., Lyalyakin V.P., Golubev I.G. Organization and technology of restoration of machine parts: scientific publication. Moscow: FGBNU Rosinformagroteh, 2016. 568 p.) (In Russian).

[5] Аскинази Б.М. Упрочнение и восстановление деталей машин электромеханической обработкой: монография. Москва: Машиностроение, 1989. 200 с. (Askinazi B.M. Hardening and reconditioning of machine parts electromechanical treatment. Moscow: Mashinostroenie, 1989. 200 p.) (In Russian).

[6] Dudkina N.G., Zakharov I.N. Micrononhomogeneous strain of the "white layer" produced by electromechanical treatment of a carbon steels. Mechanika. 2007. No.3(65). pp. 17-21.

[7] Gorozhankina O.V., Kopylov Y.R., Zhirkov A.A. Peculiarities of heavy electro-mechanical plating on medium carbon steel 30 and 38 ChN3MA. MATEC Web of Conferences 129, 02004 (2017). Pp. 1-5. DOI: 10.1051/matecconf/201712902004.

[8] Пастухов А.Г., Федоров С.К., Дегтярев Н.М., Жуков Е.М. Экспериментальные исследования влияния режимов ЭМО на эксплуатационные свойства рабочих поверхностей шипов крестовин. Труды ГОСНИТИ. 2014. Том 117. С. 100-104 (Pastukhov A.G., Fedorov S.K., Degtyarev N.M., Zhukov E.M. Experimental research of influence of modes EMP on operational properties of working surfaces of spikes crosses. Trudy GOSNITI. 2014. Vol. 117. pp. 100-104) (In Russian).

[9] Пастухов А.Г., Шарая О.А., Бережная И.Ш. Экспериментальные исследования режимов электромеханического упрочнения детали типа «плунжер». Труды ГОСНИТИ. 2017. Том 129. C. 148-157. (Pastukhov A.G., Sharaya O.A., Berezhnaya I.Sh. Experimental study of electromechanical modes of hardening of details of the "plunger". Trudy GOSNITI. 2017. Vol. 129. pp. 148-157) (In Russian).

[10]Морозов А.В., Кундротас К.Р. Повышение качества изготовления колесного цилиндра заднего тормоза автомобиля УАЗ применением поверхностного электромеханического дорнования. Инновации в АПК: проблемы и перспективы. 2018. No. 4 (20). С. 11-18. (Morozov A.V., Kundrotas K. R. Improving the manufacturing quality of the wheel cylinder of the UAZ rear brake using surface electromechanical mandrel. Innovations in APK: problems and prospects. 2018. No 4 (20). Pp. 11-18) (In Russian).

[11]Федоров С.К., Бондарев А.М. Влияние электромеханической обработки на износ дисков сошников. Вестник ФГОУ ВПО МГАУ. 2011. № 2. С. 70-71 (Fedorov S.K., Bondarev A.A. (Influence of electro-mechanical processing on the wear of Coulter disks. Vestnik FGOU VPO MGAU. 2011. No 2. Pp. 70-71) (In Russian).

[12] Fedorova L.V., Fedorov S.K. Serzhant A.A., Golovin V.V., Systerov S.V. Electormechanical surface hardening of tubing steels. Metal Science and Heat Treatment. 2017. 59 (3-4). pp. 173175. 